\title{
Resistance to thyroid hormone with a mutation of the thyroid $\beta$ receptor gene in an eight-month-old infant - a case report
}

\author{
Zespół oporności na hormony tarczycy spowodowany mutacją w genie \\ kodującym podjednostkę $\beta$ receptora hormonów tarczycy u 8-miesięcznego \\ niemowlęcia: opis przypadku
}

\author{
Elżbieta Foryś-Dworniczak, Carla Moran, Barbara Kalina-Faska, Ewa Małecka-Tendera, \\ Agnieszka Zachurzok
}

Department of Paediatrics and Paediatric Endocrinology, School of Medicine in Katowice, Katowice, Poland

\begin{abstract}
Introduction: Resistance to thyroid hormone $(\mathrm{RTH} \beta)$ is a rare syndrome of impaired tissue responsiveness to thyroid hormones (THs). The disorder has an autosomal dominant or recessive pattern of inheritance. Most of the reported mutations have been detected in the thyroid hormone receptor $\beta$ gene (THRB).

Case report: Authors present an eight-month-old infant with poor linear growth, decreased body weight, tachycardia, positive family history, and neonatal features suggestive of $\mathrm{RTH} \beta$. Both our patient and his mother had elevated free thyroxine, free triiodothyronine, and non-suppressed thyrotropin (TSH) concentration. The fluorescent sequencing analysis showed a heterozygous mutation c.728G $>$ A in TR $\beta$ gene. This pathogenic variant is known to be associated with THR.

Conclusions: The clinical presentation of RTH $\beta$ is variable, ranging from isolated biochemical abnormalities to symptoms of thyrotoxicosis or hypothyroidism. The syndrome should be suspected in patients with increased serum TH level, accompanied by a normal or elevated TSH concentration. The affected patients require individualised management. (Endokrynol Pol 2019; 70 (1): 124-130)
\end{abstract}

Key words: resistance to thyroid hormone; thyroid hormone receptor $\beta$; infant

\section{Streszczenie}

Wstęp: Zespół oporności na hormony tarczycy to rzadka, uwarunkowana genetycznie choroba, spowodowana zmniejszoną wrażliwością tkanek obwodowych i/lub komórek tyreotropowych przedniego płata przysadki na działanie hormonów tarczycy (HT). Najczęstszą przyczyną zespołu są punktowe mutacje w genie THR kodującym podjednostkę $\beta$ receptora hormonów tarczycy. Dziedziczenie jest autosomalne dominujące lub autosomalne recesywne.

Opis przypadku: W pracy przedstawiono opis przypadku 8-miesięcznego niemowlęcia ze słabym przyrostem masy i długości ciała, tachykardią oraz dodatnim wywiadem rodzinnym w kierunku zespołu oporności na hormony tarczycy. Zarówno u probanta, jak u jego matki stwierdzano podwyższone stężenie wolnej tyroksyny i trójjodotyroniny, przy braku supresji sekrecji tyreotropiny (TSH). Przeprowadzono sekwencjonowanie genu TR $\beta$, stwierdzając heterozygotyczną mutację c.728G >A, o której wiadomo, że może być przyczyną oporności na hormony tarczycy.

Wnioski: Obraz kliniczny zespołu oporności na hormony tarczycy jest zmienny; większość pacjentów znajduje się w stanie eutyreozy, u niektórych obok objawów niedoczynności występują objawy nadczynności gruczołu tarczowego. Zespół należy podejrzewać u pacjentów z brakiem supresji wydzielania TSH mimo podwyższonych stężeń hormonów tarczycy. Leczenie powinno być zindywidualizowane. (Endokrynol Pol 2019; 70 (1): 124-130)

Słowa kluczowe: zespół oporności na hormony tarczycy; receptor $\beta$ dla hormonów tarczycy; niemowlę

\section{Introduction}

Resistance to thyroid hormone $(\mathrm{RTH} \beta)$ is a rare syndrome of impaired tissue responsiveness to thyroid hormones (THs) $[1,2]$. The incidence of $\mathrm{RTH} \beta$ is approximately 1:40,000-1:50,000 per live births, and the inheritance is autosomal dominant or recessive [1, 3]. Nonetheless, approximately $15 \%$ of the cases are sporadic [3]. The thyroid hormone receptor (TR) had two subtypes ( $\operatorname{TR} \alpha, \operatorname{TR} \beta)$, which are encoded by genes (THRA, THRB) located on chromosomes 17 and 3, and with three main isoforms ( $\operatorname{TR} \alpha, \operatorname{TR} \beta 1, \operatorname{TR} \beta 2)$ with organ-specific distribution [4].

The most common causes of the syndrome are genetic mutations in THRB gene [2,5]. However, in some cases no mutations have been detected [6]. Recent studies have demonstrated THRA mutations, producing defective TR $\alpha$, as another cause of RTH (termed 
$\mathrm{RTH} \beta$ ) [7]. The RTH $\beta$ used to be classified into generalised (GRTH) or pituitary (PRTH) [8]. The clinical manifestation is heterogeneous, even between members of the same family harbouring the same mutation. The syndrome can present with variable symptoms, ranging from isolated biochemical abnormalities to symptoms of thyrotoxicosis or hypothyroidism. The biochemical hallmark of $\mathrm{RTH} \beta$ is elevated serum TH, along with non-suppressed level of thyrotropin (TSH). The treatment decision should be individualised, depending on the clinical presentation in each patient $[2,9,10]$.

\section{Case report}

An eight-month-old boy was referred to the Department of Paediatrics and Paediatric Endocrinology due to abnormal thyroid function test: elevated free thyroxine (FT4) and free triiodothyronine (FT3) concentration, along with TSH level within the normal range, accompanied by poor weight gain and tachycardia.

He was born as the first child of nonconsanguineous parents, by Caesarean section at gestational week 36, due to pregnancy complicated by oligohydramnios, breech presentation, and premature obsolescence of placenta. Additionally, during the third trimester of pregnancy growth retardation and acceleration and deceleration of foetal heart rate were observed. The birth weight was $2300 \mathrm{~g}\left(3^{\text {rd }}-10^{\text {th }}\right.$ centile, SDS: -1.65$)$ and length was $51 \mathrm{~cm}\left(75^{\text {th }}-90^{\text {th }}\right.$ centile, SDS: +2.6$)$. The birth head circumference was $32 \mathrm{~cm}\left(3^{\text {rd }}-10^{\text {th }}\right.$ centile), and the size of the anterior fontanelle in the perinatal period was $1 \times 1 \mathrm{~cm}$. To evaluate the birth parameters the growth charts by Palczewska and Niedźwiecka for boys born between 32 and 37 week of gestation $(\mathrm{Hbd})$ were used $[11,12]$. The postnatal period was complicated by feeding difficulties, due to weak sucking reflex and retrognathia. Significant failure of thrive was noted, with weight remaining below the $3^{\text {rd }}$ centile. Due to his positive family history and suggestive neonatal features of $\mathrm{RTH} \beta$, THs were checked, revealing FT4 and FT3 levels exceeding the upper limit of normal range, accompanied by normal TSH concentration.

On admission to the hospital at age eight months, the patient's length was $67 \mathrm{~cm}\left(25^{\text {th }}\right.$ centile $)$ and his weight was $5.7 \mathrm{~kg}$ ( $<3^{\text {rd }}$ centile) [12]. Physical examination showed microcephaly (head circumference: 41 $\mathrm{cm},<3^{\text {rd }}$ centile), closed anterior fontanelle, facial dysmorphia (almond-shaped, slanted eyes, flat philtrum), dry skin, very scarce subcutaneous fat tissue development, and tachycardia (160 bpm) [12]. Laboratory findings included: FT3 $13.11 \mathrm{pg} / \mathrm{ml}$ (reference range: $2.15-5.83 \mathrm{pg} / \mathrm{ml}$ ), FT4 $4.00 \mathrm{ng} / \mathrm{dL}$ (reference range: $0.65-2.30 \mathrm{ng} / \mathrm{dL}$ ), TSH $5.390 \mu \mathrm{IU} / \mathrm{mL}$ (reference range: 0.730-8.350 $\mu \mathrm{IU} / \mathrm{mL}$ ), antiTG < $20.0 \mathrm{IU} / \mathrm{ml}$ (reference range: $0.0-40.0 \mathrm{IU} / \mathrm{ml}$ ), and antiTPO $<10.0 \mathrm{IU} / \mathrm{ml}$ (reference range: $0.0-40.0 \mathrm{IU} / \mathrm{ml}$ ), TRAb $1.29 \mathrm{IU} / 1$ (reference range: < $2 \mathrm{IU} / \mathrm{l})$. To exclude a TSH-secreting pituitary adenoma a thyrotropin-releasing hormone (TRH) stimulation test was performed, and it showed a robust TSH response (time $0^{\prime}-4.7 \mu \mathrm{IU} / \mathrm{mL}, 20^{\prime}-59.67 \mu \mathrm{IU} / \mathrm{mL}$, $30^{\prime}-57.36 \mu \mathrm{IU} / \mathrm{mL}, 60^{\prime}-32.52 \mu \mathrm{IU} / \mathrm{mL}, 120^{\prime}-23.43$ $\mu \mathrm{IU} / \mathrm{mL})$. The results of complete blood count, renal and liver function, blood glucose, and routine urinalysis were within normal ranges. The result of biochemical analyses performed at the Institute of Metabolic Science are included in Table I.

Electrocardiography confirmed sinus tachycardia. Bone age was delayed and assessed as neonatal (Fig. 1). Ultrasound of the thyroid gland revealed no thyroid enlargement and no increased vascular flow pattern on Colour Doppler examination; echogenicity

Table I. The result of biochemical analyses performed at Institute of Metabolic Science; Addenbrooke's Hospital; Cambridge Tabela I. Wyniki analiz biochemicznych przeprowadzonych w Instytucie Nauk Metabolicznych (Addenbrooke's Hospital; Cambridge)

\begin{tabular}{lcc}
\hline & Proband & Proband's mother \\
\hline TSH (Delfia) & $2.75[0.40-4.00 \mathrm{mU} / \mathrm{L}]$ & $1.44[0.40-4.00 \mathrm{mU} / \mathrm{L}]$ \\
\hline Free T4 (Delfia) & $\mathbf{3 7 . 3}[9.0-20.0 \mathrm{pmol} / \mathrm{L}]$ & $\mathbf{3 0 . 0}[9.0-20.0 \mathrm{pmol} / \mathrm{L}]$ \\
\hline Calculated free T4 & 45.0 & 29.0 \\
\hline Free T3 (Delfia) & $\mathbf{1 0 . 9}[3.0-7.5 \mathrm{pmol} / \mathrm{L}]$ & $\mathbf{1 0 . 1}[3.0-7.5 \mathrm{pmol} / \mathrm{L}]$ \\
\hline Total T4 & $\mathbf{2 9 6 . 0}[69.0-141.0 \mathrm{nmol} / \mathrm{L}]$ & $\mathbf{2 4 1 . 0}[69.0-141.0 \mathrm{nmol} / \mathrm{L}]$ \\
\hline TBG & $25.4[14.0-31.0 \mathrm{ug} / \mathrm{ml}]$ & $26.7[14.0-31.0 \mathrm{ug} / \mathrm{ml}]$ \\
\hline TSH (Siemens Centaur) & $3.25[0.35-5.50 \mathrm{mU} / \mathrm{L}]$ & $1.59[0.35-5.50 \mathrm{mU} / \mathrm{L}]$ \\
\hline Free T4 (Siemens Centaur) & $\mathbf{3 5 . 8}[10.0-19.8 \mathrm{pmol} / \mathrm{L}]$ & $\mathbf{2 6 . 8}[10.0-19.8 \mathrm{pmol} / \mathrm{L}]$ \\
\hline Free T3 (Siemens Centaur) & $\mathbf{1 0 . 2}[4.3-7.6 \mathrm{pmol} / \mathrm{L}]$ & $\mathbf{9 . 0}[3.5-6.5 \mathrm{pmol} / \mathrm{L}]$
\end{tabular}

$\mathrm{TSH}$ - thyroid-stimulating hormone; T4 — thyroxine; T3 — triiodothyronine; TBG — thyroxine-binding protein 


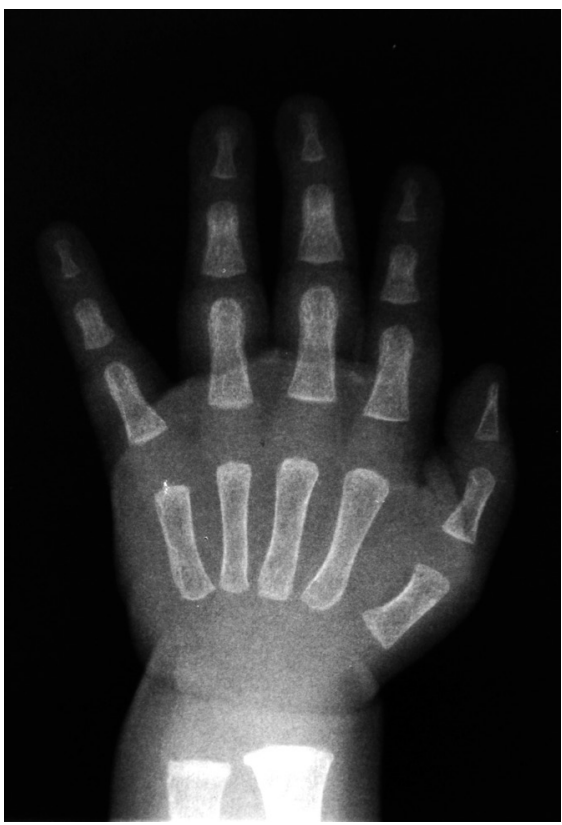

Figure 1. Radiograph of the left hand taken at the age of 8 months. Bone maturation was delayed and assessed as neonatal

Rycina 1. Badanie RTG lewej ręki przeprowadzone u probanda w wieku 8 miesięcy. Widoczne opóźnione dojrzewanie kości, oceniano je jako noworodkowe

was moderately decreased and heterogeneous. The psychomotor development was assessed as average for the child's age.

The patient's mother also presented abnormal thyroid function. She was born at 41 weeks of gestation with low birth weight $\left(2270 \mathrm{~g},<3^{\text {rd }}\right.$ centile $)$ and low length $\left(50 \mathrm{~cm},<3^{\text {rd }}\right.$ centile) [13]. Her current weight and height were $50 \mathrm{~kg}\left(10^{\text {th }}-25^{\text {th }}\right.$ centile, -1.4 SDS) and $156 \mathrm{~cm}\left(3^{\text {rd }}-10^{\text {th }}\right.$ centile, $\left.-1.67 \mathrm{SDS}\right)$, and her BMI was $20.6 \mathrm{~kg} / \mathrm{m}^{2}$. She had suffered from persistent tachycardia since childhood. Additionally, as a child she exhibited attention deficit, hyperirritability, and learning difficulties. The patient's mother was misdiagnosed for several years. Finally, in adulthood, she was referred to the endocrinologist due to persistent elevation of serum level of FT3 and FT4 with normal TSH concentration. AntiTg, antiTPO, and TRAb autoantibodies were negative. Her thyroid function panels are reviewed and presented in Table II. Oral administration of metizol (thiamazole) did not lead to normalisation of THs or clinical improvement. Anti-thyroid drug therapy was continued during pregnancy. Additionally, she was also treated empirically with a beta-blocker. Ultrasonography of her thyroid showed the gland to be of normal volume with a single nodule in the left lobe (colloid nodule diagnosed in fine needle biopsy). The pituitary MRI was normal, and no adenoma was found. After exclusion of the possibility of TSH-producing pituitary adenoma, the diagnosis of $\operatorname{RTH} \beta$ was highly suspected. However, no genetic test was performed at this time. It is noteworthy that also the proband's grandmother had a medical history of thyroidectomy due to goitre in the course of hyperthyroidism. The genetic tests were performed in the proband and his mother. Fluorescent sequencing analysis detected a heterozygous base change, c.728G $>$ A, in exon 7 of THRB gene in the child as well as in his mother. This pathogenic variant is predicted to result in abnormal $\mathrm{TR} \beta$ protein (p.Arg243Gln) and has been previously associated with $\operatorname{RTH} \beta$ [14].

Normalisation of the patient's heart rate and blood pressure were initially obtained by the administration of the $\beta$-blocker (propranolol, $2.5 \mathrm{mg}$ twice a day). For the last two years the boy has remained under the care of an endocrine outpatient clinic. During this time his THs concentration stayed elevated with non-suppressed TSH level (Tab. III). Ultrasound of the thyroid gland showed a minor enlargement of the thyroid. The main clinical problem was persistent (mild) tachycardia (100-120 bpm on average), hyperactivity, and failure to thrive. His current weight, at the age of three years and six months, is $9.9 \mathrm{~kg}\left(<3^{\text {rd }}\right.$ centile, -4.07 SDS $)$ and his height is $89.7\left(<3^{\text {rd }}\right.$ centile, -2.88 SDS) [13] (Fig. 2, 3). Additionally, the bone age,

Table II. Thyroid function panel of proband's mother from 2012 to 2015

Table II. Wyniki badań czynności tarczycy matki probanda w latach 2012-2015

\begin{tabular}{lccccccccccc}
\hline & $\begin{array}{c}\text { Reference } \\
\text { value }\end{array}$ & $\mathbf{0 5 / 2 0 1 2}$ & $\mathbf{0 7 / 2 0 1 3}$ & $\mathbf{0 1 / 2 0 1 4}$ & $\mathbf{0 2 / 2 0 1 4}$ & $\mathbf{0 6 / 2 0 1 4}$ & $\mathbf{0 9 / 2 0 1 4}$ & $\mathbf{1 0 / 2 0 1 4}$ & $\mathbf{1 1 / 2 0 1 4}$ & $\mathbf{1 2 / 2 0 1 4}$ & $\mathbf{0 2 / 2 0 1 5}$ \\
\hline TSH [mU/L] & $0.270-4.200$ & 2.200 & 2.620 & 1.730 & 1.540 & 1.340 & 1.680 & 2.88 & 2.01 & 1.730 & 2.240 \\
\hline FT4 [pmol/L] & $12.00-22.00$ & 41.33 & 30.98 & 40.36 & 35.48 & 36.19 & 36.29 & 32.56 & 28.57 & 23.33 & 22.98 \\
\hline FT3 [pmol/L] & $3.10-6.80$ & 10.88 & 9.82 & 10.62 & 8.87 & 7.62 & 10.4 & 12.78 & 10.86 & 9.24 & 9.16 \\
\hline $\begin{array}{l}\text { Dose } \\
\text { of tiamazol } \\
\text { [mg/d] }\end{array}$ & & - & 10 & - & - & - & - & - & 5 & 2.5 & 2.5 \\
\hline
\end{tabular}

TSH — thyroid-stimulating hormone; FT4 — free thyroxine; FT3 — free triiodothyronine 
Table III. Thyroid function panel of proband from 2016 to 2017

Table II. Wyniki badań czynności tarczycy probanda w latach 2016-2017

\begin{tabular}{lccccc}
\hline & Reference value & $\mathbf{0 5 / 2 0 1 6}$ & $\mathbf{0 1 / 2 0 1 6}$ & $\mathbf{0 8 / 2 0 1 7}$ & $\mathbf{0 9 / 2 0 1 8}$ \\
\hline TSH [ulU/mL] & $0.700-5.970$ & 4.060 & 2.320 & 3.63 & 3.02 \\
\hline FT4 [ng/dL] & $0.65-2.3$ & 2.74 & 3.51 & 2.75 & 3.00 \\
\hline FT3 [pg/mL] & $2.41-5.50$ & 7.29 & 8.21 & & 9.68 \\
\hline
\end{tabular}

$\mathrm{TSH}$ — thyroid-stimulating hormone; FT4 — free thyroxine; FT3 — free triiodothyronine

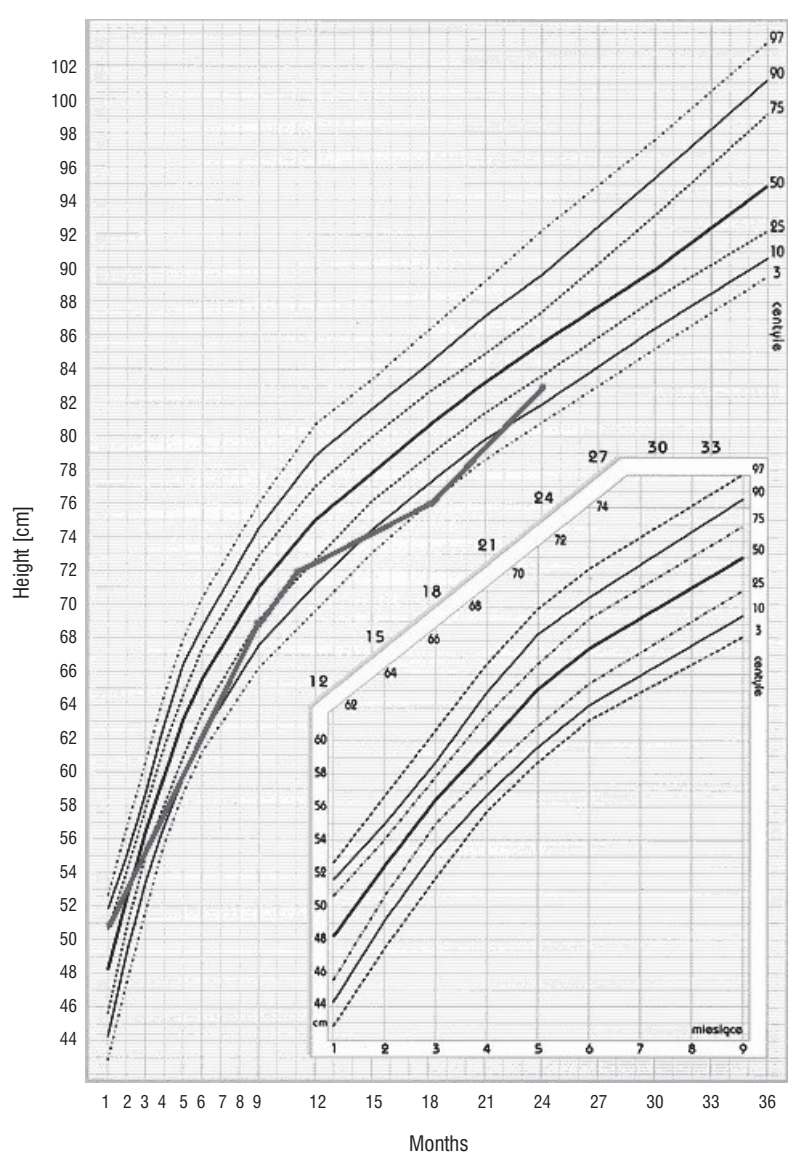

Figure 2. The growth curve of the proband according to the height growth chart by Palczewska and Niedźwiecka for boys born between 32 and $37 \mathrm{Hbd}$

Rycina 2. Krzywa wzrostu probanda zgodnie z siatka centylowa Palczewskiej i Niedźwieckiej dla chłopców urodzonych między 32. i 37. tygodniem ciązy

assessed according to the Greulich and Pyle method, was significantly delayed and asynchronous (wrist bone age and metacarpal bone age: three month, phalanges bone age: one year and six months - two years) (Fig. 4). Treatment with a $\beta$-blocker was stopped due to poor drug tolerability (anxiety, nightmares). No anti-thyroid drug treatment was introduced. Due to the relatively mild presentation of the disease, absence of severe tachycardia, stabilisation in growth, and normal development of the child, more aggressive treatment has not been needed so far.

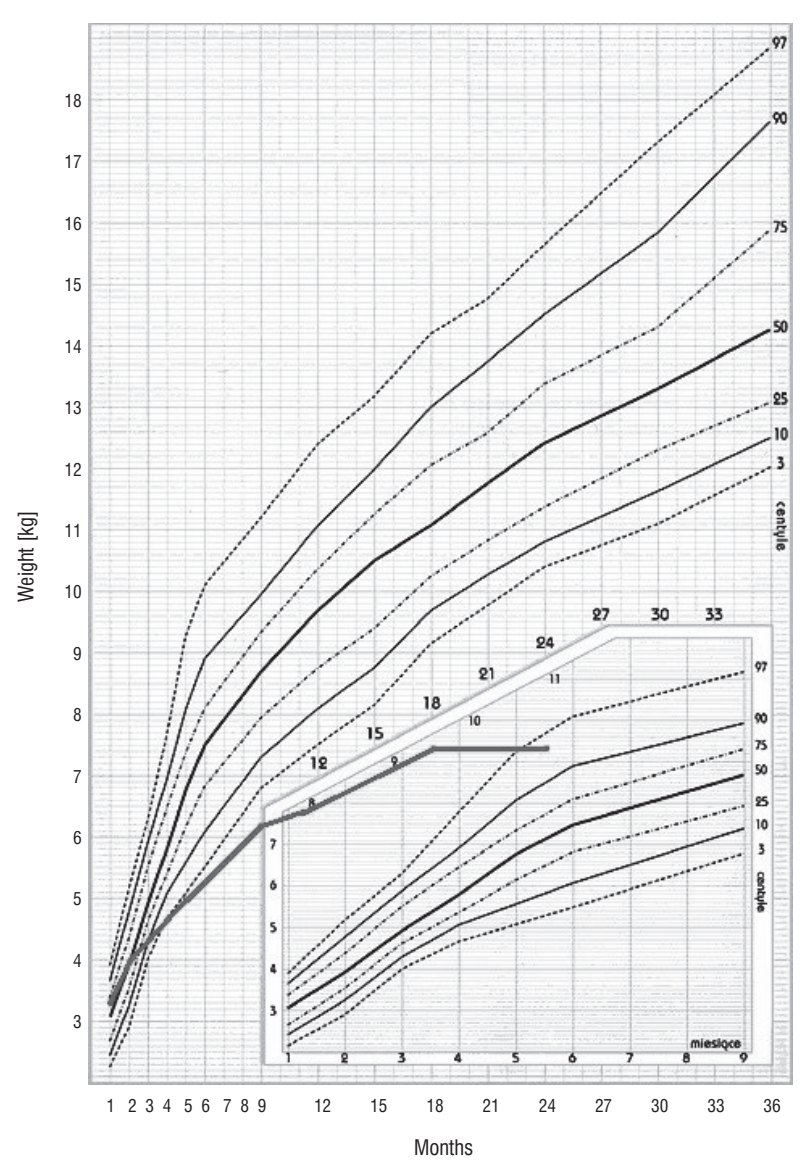

Figure 3. The weight curve of the proband according to the weight growth chart by Palczewska and Niedźwiecka for boys born between 32 and $37 \mathrm{Hbd}$

Figure 3. Krzywa masy ciała probanda zgodnie z siatka centylowa Palczewskiej i Niedźwieckiej dla chłopców urodzonych między 32. i 37. tygodniem ciaży

\section{Discussion}

Resistance to thyroid hormone is a rare genetic disorder with an autosomal dominant or recessive model of inheritance, characterised by various clinical presentations even within the families with the same mutation $[1,2]$. The first case of RTH syndrome was reported by Refetoff et al. in 1967.

The thyroid hormone receptor belongs to the nuclear receptor superfamily and has four functional domains: transcription activation domain, DNA-bind- 


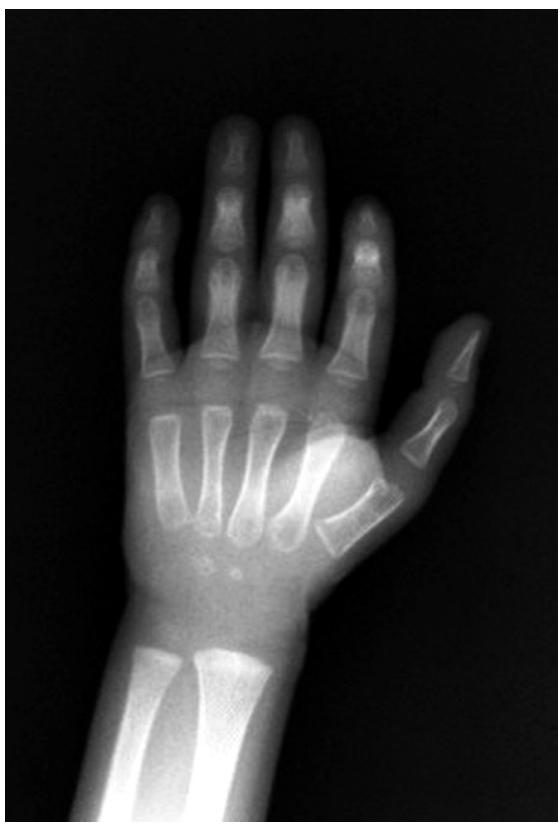

Figure 4. Radiograph of the left hand taken at the age of 3 years and 6 months. Bone maturation was delayed and asynchronous (wrist bone age and metacarpal bone age: 3 months, phalanges bone age: 1 year and 6 months - 2 years)

Rycina 4. Badanie RTG lewej ręki przeprowadzone u probanda w wieku 3 lat i 6 miesięcy. Widoczne opóźnione i niesynchroniczne dojrzewanie kości (kość nadgarstka i kość śródręcza: wiek oceniono na 3 miesiace, paliczki palców: wiek oceniono na 1,5-2 lata)

ing domain, hinge region, and ligand binding domain. Each of the thyroid hormone receptors (TR $\alpha, \operatorname{TR} \beta)$ has two different isoforms. Only TR $\alpha 1$, TR $\beta 1$, and TR $\beta 2$ are able to bind THs. The receptors have specific organ distribution. TR $\alpha 1$ is widely expressed, especially in cardiac and skeletal muscles, gastrointestinal tract, and central nervous system (CNS). TR $\beta 1$ is mainly expressed in brain, liver, and kidney; TR $\beta 2$ expression is primarily limited to the hypothalamus and pituitary [4]. TR $\alpha 2$ is also widely expressed but unable to bind hormones; its function is not fully understood.

Approximately $85 \%$ of individuals with $\mathrm{RTH} \beta$ have a THRB mutation $[2,5]$. Approximately 170 different mutations of the THRB gene have been described. Most of the mutations are single-nucleotide substitutions [5, 15]. The majority of them are located in three hotspot regions between exon 7 and 10 [16]. Mutations may result in reduced or absent $\mathrm{T} 3$ binding to the mutant receptor; some mutant TR $\beta$ have an abnormal interaction with coactivators and corepressors involved in mediating TH action via the receptor. Additionally, mutant receptors are characterised by dominant negative activity and are capable of interfering with the function of the wild-type receptor [16]. The mutation identified in our proband and his mother was first described by Onigata et al. in 1995. This single nucleotide substitution, guanine for adenine, was identified at the second position of 243 codon located in the hinge domain between the ligand binding and DNA binding domains, resulting in the substitution of arginine with glutamine. This leads to reduced ligand affinity but also to inhibition of wild-type $\operatorname{TR} \beta$ action in a dominant negative manner. Reversal of the inhibition is possible with the higher T3 concentration [14].

The clinical presentation of $\mathrm{RTH} \beta$ is variable, from completely asymptomatic to hyper- or hypothyroid signs and symptoms or a combination of them [9]. The variability seen in the clinical presentation could be explained by different tissue distribution of TR isoforms, individual tolerance to elevated THs levels, or varying mutant TR tissue expression [17]. The RTH syndrome has been classified into generalised (GRTH) or pituitary (PRTH) $[2,8]$. Approximately $80 \%$ of cases belong to GRTH type. The majority of patients with GRTH are clinically euthyroid. Patients with PRTH exhibit symptoms of tissue-specific mild to moderate hyperthyroidism. However, in some cases, differentiating selective PRTH from GRTH may be difficult. [2, 9].

Early goitre development is one of the most common clinical findings, and it is observed in 66-95\% of $\mathrm{RTH} \beta$ patients. Enlargement of the thyroid is related to the continuously high level of TSH that stimulates the thyroid to overgrow. Some individuals present symptoms of TH insufficiency, such as growth retardation with delayed bone age, intellectual impairment, or hypercholesterolaemia. Recent studies showed that approximately $50 \%$ of patients have learning disabilities, such as Attention Deficient Hyperactivity Disorder (ADHD) and lower intellectual quotients. However, mental retardation $(\mathrm{IQ}<60$ ) occurs exclusively in 3\% of cases. Many individuals manifest signs of TH excess, such as sinus tachycardia (80-90\%), advanced bone maturation, or hyperactivity. Some patients may also present combination of symptoms of $\mathrm{TH}$ deficiency and excess [9]. It has been observed that the symptoms become milder with age. Patients with homozygous mutations in THRB exhibit a more severe phenotype. Other common complaints include recurrent ear infection and sensorineural deafness. The individuals also present dysmorphic features such as bird-like facies with prominent nasal bridge, pigeon chest, or winged scapulae. This severe phenotype is probably due to the dominant negative effect of the mutant protein and the lack of functional TR $\beta[18,19]$. In our patient a combination of hypo- and hyperthyroidism symptoms was observed. He is a carrier of heterozygous mutation in THRB, and some symptoms of TH excess are present (tachycardia, hyperactivity, poor weight gain); however, they are not severe. Moreover, some features suggesting hypothyroidism (delayed bone age) were also observed. 
The syndrome should be suspected in patients with increased serum TH level accompanied by a normal or elevated TSH concentration. Due to lack of pathognomonic symptoms associated with $\mathrm{RTH} \beta$, the diagnosis of this disorder should be confirmed by the clinical examination, laboratory findings, and gene mutation analysis. Because of variability of the clinical presentation of $\mathrm{RTH} \beta$ syndrome, affected patients require individualised management. Avoidance of inappropriate treatment is especially important when managing infants and children.

At present, specific treatments for $\mathrm{RTH} \beta$ are not available. The majority of affected patients compensate for tissue resistance by increased endogenous supply of TH and do not require therapy [10]. The administration of TH is reserved for individuals with insufficient tissue hyposensitivity compensation, especially in cases of autoimmune thyroiditis coincidence. The aim of the therapy is to diminish symptoms of hypothyroidism and to reduce serum TSH concentration to a normal level. The optimal dose of exogenous TH is variable and highly individual. Patients with RTH $\beta$ with evidence of hypothyroidism (elevated TSH, symptoms of hypothyroidism, positive anti-TPO antibodies) require the administration of supraphysiological, incremental doses of levothyroxine (LT4). This therapy requires careful monitoring of markers of TH action, such as SHBG, cholesterol profile, basal metabolic rate (if possible), and bone density. Thyroidectomy is been reserved for individuals with pronounced hyperthyroid symptoms and compressive goitre, which cannot be controlled medically [20].

Patients with RTH $\beta$ with symptoms of hyperthyroidism should be treated symptomatically. Administration of $\beta$-blockers improves tachycardia and tremor. Treatment with dopaminergic drugs and somatostatin analogues, due to only transient benefits, have limited use. The thyroid hormone analogue triiodothyroacetic acid (TRIAC) is used in cases of individuals with PRTH with selective resistance accompanied by symptoms of hyperthyroidism. However, whether TRIAC has beneficial effects on all markers of TH action is not known [21].

Treatment of affected infants still remains controversial. It is proposed that TH therapy (usually LT4) should be reserved for children with elevated serum TSH levels and developmental failure that cannot be explained by other illness or defect, or family history of growth or mental retardation [10]. Some authors have suggested short-term treatment with methimazole and iodine in hyperthyroid RTH $\beta$ neonates [22]. Interestingly, liothyronine therapy may alleviate the symptoms of ADHD in a significant number of RTH $\beta$ children [23]. In our patient, due to relatively mild symptoms, we decided against the use of anti-thyroid drugs and used beta-blockers to control tachycardia. Unfortunately, we had to discontinue therapy due to the side effects. The patient is now carefully followed by endocrinology and cardiology, and his thyroid function is regularly checked.

\section{Conclusion}

We describe a case of RTH $\beta$ caused by a common germline mutation located at THRB exon 7 hot spot. In our study, both the patient and his mother had elevated FT3, FT4, and non-suppressed TSH concentration. They presented symptoms of hyperthyroidism, such as tachycardia, hyperactivity, and poor weight gain. It can be concluded that despite the rarity and atypical clinical presentation of the $\mathrm{RTH} \beta$, primary care physicians, paediatricians, and endocrinologists should consider this diagnosis when evaluating individuals with hyperthyroxinaemia and non-suppressed TSH levels. The treatment should be individualised, but no therapy is fully effective.

\section{References}

1. Refetoff S. Resistance to thyroid hormone with and without receptor gene mutations. Ann Endocrinol. (Paris). 2003; 64(1): 23-25, indexed in Pubmed: 12707628

2. Agrawal NK, Goyal R, Rastogi A, et al. Thyroid hormone resistance. Postgrad Med J. 2008; 84(995): 473-477, doi: 10.1136/pgmj.2008.069740, indexed in Pubmed: 18940949.Lafranchi SH, Snyder DB, Sesser DE, et al. Follow-up of newborns with elevated screening T4 concentrations. J Pediatr. 2003; 143(3): 296-301, doi: 10.1067/S0022-3476(03)00184-7, indexed in Pubmed: 14517508 .

3. Flamant F, Baxter JD, Forrest D. International Union of Pharmacology. LIX. The pharmacology and classification of the nuclear receptor superfamily: thyroid hormone receptors. Pharmacol Rev. 2006; 58(4): 705-711, doi: 10.1124/pr.58.4.3, indexed in Pubmed: 17132849.

4. Refetoff S, Dumitrescu AM. Syndromes of reduced sensitivity to thyroid hormone: genetic defects in hormone receptors, cell transporters and deiodination. Best Pract Res Clin Endocrinol Metab. 2007; 21(2): 277-305, doi: 10.1016/j.beem.2007.03.005, indexed in Pubmed: 17574009.

5. Pohlenz J, Weiss RE, Macchia PE. Five New Families with Resistance to Thyroid Hormone not Caused by Mutations in the Thyroid Hormone Receptor Gene. J Clin Endocrinol Metab. 1999; 84(11): 3919-3928, doi: 10.1210/jc.84.11.3919.

6. Bochukova E, Schoenmakers N, Agostini M, et al. A mutation in the thyroid hormone receptor alpha gene. N Engl J Med. 2012; 366(3): 243-249, doi: 10.1056/NEJMoa1110296, indexed in Pubmed: 22168587.

7. Refetoff S. Resistance to thyroid hormone. In: Braverman LE, Utiger RE. ed. Werner and Ingbar's The thyroid: a fundamental and clinical text. 9th ed. Lippincott, Williams and Wilkins, Philadelphia 2005: 1109-1129.

8. Beck-Peccoz P, Chatterjee VK. The variable clinical phenotype in thyroid hormone resistance syndrome. Thyroid. 1994; 4(2): 225-232, doi: 10.1089/thy.1994.4.225, indexed in Pubmed: 7920008.

9. Weiss RE, Refetoff $S$. Treatment of resistance to thyroid hormone — primum non nocere. J Clin Endocrinol Metab. 1999; 84(2): 401-404, doi: 10.1210/jcem.84.2.5534, indexed in Pubmed: 10022391.

10. Niklasson A, Albertsson-Wikland K. Continuous growth reference from 24 th week of gestation to 24 months by gender. BMC Pediatr. 2008; $8(8)$, doi: 10.1186/1471-2431-8-8, indexed in Pubmed: 18307822.

11. Niedźwiecka Z, Palczewska I. Wskaźniki rozwoju fizycznego w pierwszych trzech latach życia dzieci urodzonych przedwcześnie. Medycyna Wieku Rozwojowego. 1997; 1(supl. 1): 3-71.

12. Palczewska I, Nieźwiecka Z. Wskaźniki rozwoju somatycznego dzieci i młodzieży warszawskiej. Medycyna Wieku Rozwojowego, 2001; 5. ; 52(supl. 1): 113-114.

13. Onigata K, Yagi H, Sakurai A, et al. A novel point mutation (R243Q) in exon 7 of the c-erbA beta thyroid hormone receptor gene in a fam- 
ily with resistance to thyroid hormone. Thyroid. 1995; 5(5): 355-358, doi: 10.1089/thy.1995.5.355, indexed in Pubmed: 8563471

14. Onigata K, Szinnai G. Resistance to thyroid hormone. Endocr Dev. 2014; 26: 118-129, doi: 10.1159/000363159, indexed in Pubmed: 25231448.

15. Yen PM. Molecular basis of resistance to thyroid hormone. Trends Endocrinol Metab. 2003; 14(7): 327-333, indexed in Pubmed: 12946875.

16. Mixson AJ, Hauser P, Tennyson G, et al. Differential expression of mutant and normal beta $\mathrm{T} 3$ receptor alleles in kindreds with generalized resistance to thyroid hormone. J Clin Invest. 1993; 91(5): 2296-2300, doi: 10.1172/JCI116458, indexed in Pubmed: 8486789.

17. Frank-Raue K, Lorenz A, Haag C, et al. Severe form of thyroid hormone resistance in a patient with homozygous/hemizygous mutation of T3 receptor gene. Eur J Endocrinol. 2004; 150(6): 819-823, doi: 10.1530/eje.0.1500819, indexed in Pubmed: 15191352

18. Ferrara AM, Onigata K, Ercan O, et al. Homozygous thyroid hormone receptor -gene mutations in resistance to thyroid hormone: three new cases and review of the literature. J Clin Endocrinol Metab. 2012; 97(4): 1328-1336, doi: 10.1210/jc.2011-2642, indexed in Pubmed: 22319036

19. Canadas KT, Rivkees SA, Udelsman R, et al. Resistance to thyroid hormone associated with a novel mutation of the thyroid receptor gene in a four-year-old female. Int J Pediatr Endocrinol. 2011; 2011(1): 3 , doi: 10.1186/1687-9856-2011-3, indexed in Pubmed: 21860630.

20. Weiss RE. Management of patients with resistance to thyroid hormone. Thyroid Today. 1999; 12: 1-11.

21. Yatsuga S, Hiromatsu Y, Sasaki S, et al. A two-day-old hyperthyroid neonate with thyroid hormone resistance born to a mother with well-controlled Graves' disease: a case report. J Med Case Rep. 2012; 6 : 246, doi: 10.1186/1752-1947-6-246, indexed in Pubmed: 22905724.

22. Weiss RE, Stein MA, Refetoff $S$. Behavioral effects of liothyronine (L-T3) in children with attention deficit hyperactivity disorder in the presence and absence of resistance to thyroid hormone. Thyroid. 1997; 7(3): 389-393, doi: 10.1089/thy.1997.7.389, indexed in Pubmed: 9226208 